\title{
Conservation informed by the fossil record
}

\author{
Rafał Nawrot \\ Acta Palaeontologica Polonica 63 (4), 2018: 736-736 doi:http://doi.org/10.4202/app.00549.2018
}

Gregory P. Dietl and Karl W. Flessa (eds.) 2017. Conservation Paleobiology: Science and Practice. 336 pp. University of Chicago Press, Chicago. ISBN 978-0-226-50672-2 (paper). Price \$40.00; e-book $\$ 10.00-40.00$.

Rafał Nawrot [rnawrot@flmnh.ufl.edu], Florida Museum of Natural History, University of Florida, 1659 Museum Road, Gainesville, FL 32611 USA.

This is an open-access article distributed under the terms of the Creative Commons Attribution License (for details please see creativecommons.org), which permits unrestricted use, distribution, and reproduction in any medium, provided the original author and source are credited.

FaF 